\title{
Strengthening the Highest Authority of People's Consultative Assembly Determined In The 1945 Constitution of The Republic of Indonesia In Order to Strengthen The Constitutional Check and Balances System
}

\author{
Hamrin $^{1}$ \\ \{hamrin.unhan@gmail.com\} \\ ${ }^{1}$ Doctoral Students of Law Science of Jayabaya University, Indonesia
}

\begin{abstract}
The People's Consultative Assembly is one of the representative institutions that functions to determine and revise the 1945 constitution as well as to the structure and to lay off the president (post amendment) of the 1945 constitution. Regarding with the authority of the People's Consultative Assembly, then the Check and Balances System is the requirement of the presence of balance within the government system. The research used is Normative Juridical Law. Normative law research is a literary research towards secondary data with the analysis used in this research is qualitative analysis. The research result shows the reason causing the needs of adjustment towards the arrangement, position and the authority of the People's Consultative Assembly into an institution representing the people with two chambers (bicameral). One of them is the need for Indonesia today to start applying a check and balance system in order to improve the constitutional lives and to encourage democratization. With the existence of two chambered people's representative institutions, it is expected that this institution would be able to run its legislative and control functions better.
\end{abstract}

Keywords: Authority of People's Consultative Assembly, 1945 constitution, Check and Balances System

\section{Introduction}

The position of People's Consultative Assembly (MPR)[1] on the transition to democracy must not be restored into the People's Legislative Assembly which has the highest authority.[2] However, what must be strengthened is the authority of the People's Consultative Assembly as the state institution with the highest authority. Related to the authority of the MPR as a representative institution, the check and balances system is a condition for a balance in the government system.

The main idea in checks and balances is an effort to divide the existing power into branches of power aiming to prevent the dominance of a group.[3] If all three branches of power have their own checks to each other, the checks are used to balance the power. A branch of power that takes too much power is limited through the actions of another branch of power. Checks and balances are created to limit government power. 
People's Consultative Assembly is one of the representative institutions that performs the function of establishing and amending the 1945 Constitution and inaugurating and dismissing the President (Post amendment) of the 1945 Constitution. Prior to the amendment, the function of the MPR was to establish and amend the Constitution and Guidelines for State Policy, appoint and dismiss the President, and hold the President accountable. Soetoprawiro states that MPR, based on the 1945 Constitution, was almost similar to the authority of the Gouverneur Generaal during the Dutch East Indies regulated through the Indische Staatsregeling.[4] Soekarno in a BPUPKI meeting on May 28, 1945 stated before the Head of State and Deputy Head of State that a Consultative Assembly was for all Indonesian people which is the highest power in the republic. The power held by the deliberations of all Indonesian people is occupied, not only by representatives of Indonesian regions, but also by representatives of all Indonesian groups or people, who are freely elected and independent by the people with the most votes.[5]

From the judicial point of view of state administration, there has been a change in the chamber system for the MPR to the Bicameral system, which has positioned the MPR as no longer the Supreme State Institution implementing the full sovereignty of the people. Referring to the aforementioned background, the Indonesian constitutional system is based on the new constitution and the upcoming practice of the state administration is limited to only three constitutional duties/powers of the MPR, namely: a) Amend and enact the Constitution; b) Inaugurate the President and/or Vice President; and c) Dismiss the President and/Vice President in their tenure. (Vide Article 3 paragraph (1), (2) and (3) of the 1945 Constitution after Amendment). [6]

The current basic problem related to upholding the three powers mentioned above is whether the position of the MPR must be restored as the highest representative body of the people? Regarding this issue, Megawati Soekarnoputri stated that the People's Consultative Assembly must be restored to be the highest institution of the State because it is the only institution that holds the people's sovereignty; thus, it must indeed be the highest. The MPR has thus become the embodiment of all the people, especially when the MPR upholds and carries out the three authorities that do have the highest function compared to other institutions. Why does the MPR have to be the highest state institution? It is because the MPR can appoint the president and dismiss the president through impeachment. Besides, there are authorities in which the results are higher than other State institutions, namely: a) Stipulate MPR Decree as the implementation of the 1945 Constitution; and b) Stipulate and amend the 1945 Constitution.

\section{Method}

This study used a normative juridical law. Normative legal research is a library research using secondary data.[7] By conducting library research, initial data will be obtained to be analyzed and used as material in this paper. The sources of legal material consist of secondary data and primary data. The analysis used in this study is qualitative analysis.

\section{Result and Discussion}

3.1 The Authority of the MPR Stipulated in the 1945 Constitution After Amendment 
According to Mahfud after the 1945 Constitution was changed, it was clear that democratic life was growing better. The change itself has been a huge progress for our democracy. In the past, if there was an idea to change the 1945 Constitution, it had been very taboo.[8]

The journey of the MPR experienced significant changes after the amendment of the 1945 Constitution began in the period 1999-2002. After the fourth amendment to the 1945 Constitution, fundamental change related to the structure and function of parliamentary legislation is that the MPR is no longer the highest state institution but a state institution,[9] while duties and authority of the MPR referring to amendment of the 1945 Constitution are as follows:[10]

1) Hold a meeting at least once in five years

2) Amend and enact the Constitution. A written change proposal was submitted by at least $1 / 3$ of the total number of MPR Members and the decision was made with the approval of at least fifty percent plus one of all MPR members.

3) Inaugurating the President and Vice President based on the results of the Election in the plenary session of the MPR.

4) Decide the proposal of the DPR based on the decision of the Constitutional Court to dismiss the President and/or Vice President during their tenure after the President and/or Vice President are given the opportunity to submit an explanation in the plenary session of the MPR.[11]

5) Hold a hearing to decide upon the DPR's proposal no later than thirty days after receiving the proposal.

6) Inaugurate the Vice President to be President if the President dies, quits, is dismissed, or is unable to carry out his/her obligations within his/her tenure.

7) To elect a Vice President from two candidates nominated by the President, in the event of a Vice President's absence within the tenure no later than sixty days.

8) Elect the President and Vice President if both of them terminate their tenure simultaneously no later than thirty days. With such fundamental changes, there must have been a State institutional reconstruction, in this case the MPR. For this reason, the author would like to examine whether the change in the structure of the State institutions based on the amendment of the 1945 Constitution was in accordance with the Presidential system considering the position of state institutions being equal. Amendments to the Law or State Constitution[12] will have a great influence on a country's construction because the constitution[13] is something that is very important for every nation and state, both those who have long been independent and who have just gained their independence. Corpus Juris Scundum, volume 16, defines constitution as something that is very important for every nation and state, both long-term independence and who have just gained independence.

After the amendment of the 1945 Constitution, Article 1 paragraph (2) underwent a change, that is, the sovereignty is in the hands of the people and is carried out according to the Constitution. With this change, the MPR is no longer the highest state institution but equal to other state institutions. Its authority is only limited to changing and stipulating the Constitution, inaugurating the President and Vice President, and dismissing the President and/or Vice President during the tenure based on the Constitution. The composition of the MPR has also been amended. Article 2 paragraph (1) of the 1945 Constitution after the Amendment confirms that the MPR members consist of members of the DPR and DPD who are elected from the elections. This representative system is known as a bicameral system. 


\subsection{Strengthening the Highest Authority of the MPR Stipulated in the 1945 Constitution of the Republic of Indonesia in the Context of Strengthening the State Administration Check and Balances System}

The Indonesian MPR Assessment Institute concludes the following opinions:[14]

1) Maintaining the principles and implementation of people's sovereignty and the position and authority of the People's Consultative Assembly after the amendment of the 1945 Constitution of the Republic of Indonesia.

a) The Indonesian state was formed on the basis of the will of the people to realize the ideals of the noble people as affirmed in the Vision and Mission of an independent Indonesia contained in the Preamble of the 1945 Constitution of the Republic of Indonesia. Therefore, all efforts to realize the Vision and Mission must not reduce or even continue to strengthen the people's sovereignty as referred to in Pancasila.

b) The principle of popular sovereignty is contained in Precepts IV of Pancasila which must be understood in a holistic wholeness with other precepts. Sila IV reads: Democracy guided by the inner wisdom in the unanimity arising out of deliberations among representatives. It means that the demands of the people as individuals and the community as a group are deliberated in the institutions of people's representatives which include aspects of the executive, legislative, judicial, and auditive. Therefore, it is not only fully implemented by a state institution in a hegemonic manner.

c) As understood, the realization of the Vision and Mission of an independent Indonesia as stipulated in the Preamble of the 1945 Constitution of the Republic of Indonesia is very dependent on the determination, enthusiasm, discipline and obedience of the state administrators and all Indonesian people in the Pancasila and the 1945 Constitution of the Republic of Indonesia. Therefore, all forms of irregularities that have occurred to this day need to be assessed whether it is true that there has been a irregularities in the formulation of the articles of the 1945 Constitution of the Republic of Indonesia or in manifestation through laws or also in the policies and procedures in all implementation practices of the nation.

d) Article 1 paragraph (2) emphasizes that people's sovereignty must always be kept in the hands of the people, only the implementation is regulated in the 1945 Constitution of the Republic of Indonesia. The provisions in Article 1 paragraph (2) also emphasize the supremacy of the constitution and not the supremacy of the MPR because the Indonesian state adheres to constitutional understanding. Constitutionalism places the 1945 Constitution of the Republic of Indonesia as the highest basic law. All state institutions, government agencies and social institutions as well as political institutions and all citizens must comply with the provisions stipulated in the 1945 Constitution of the Republic of Indonesia. The MPR has the authority to amend and enact the Constitution but must also submit to the provisions stipulated in the Constitution.

2) It maintains the principles and implementation of people's sovereignty and the position and authority of the MPR after the amendment to the 1945 Constitution of the Republic of Indonesia by adding the MPR's authority to determine the GBHN, with two kinds of formulations of authority.

a) Variety 1

Adding the MPR's authority to determine the GBHN through Amendments to the 1945 Constitution of the Republic of Indonesia. 
i. The current national condition shows that the structure and process of formulating national interests is fragmented according to the platforms and programs of the President, Governor, Regent, and Mayor, so that various conflicts and disharmony of national and regional development emerge. There have been many processes of omission of natural resource exploration, and various national security problems have arisen in the context of globalization which greatly threatens the survival of the nation and state of the Republic of Indonesia.

ii. Ideally, the National Development Planning System as per the GBHN model is a legal document for the organizers of national development based on popular sovereignty. This means that it is the people through their representatives in the MPR institution who make, establish, and monitor it. The state direction document or national development planning that has been prepared and established by the MPR is then mandated to the President to be implemented.

iii. It requires an amendment to the 1945 Constitution of the Republic of Indonesia to add MPR authority to determine the GBHN as the direction and strategy of national development.

b) Variety 2

Adding other provisions as a consequence of the MPR's authority to determine the GBHN.

i. MPR supervision function is needed for the implementation of the GBHN.

ii. In the framework of supervision, the MPR holds an Annual Session as a means for state institutions to submit performance reports.

iii. These provisions are part of the proposed Amendment to the 1945 Constitution of the Republic of Indonesia.

3) Restore the position and authority of the MPR as the full perpetrators of the people's sovereignty (the highest state institution).

a) The founding fathers were aware that the Republic of Indonesia that was built must be a stable State. Therefore, it is necessary to design a Political and Government System that can guarantee the stability of the administration of the State that will advance Indonesia. The experience of the Indonesian people in developing themselves since the early 1970 s by using a system of popular sovereignty carried out entirely by the People's Consultative Assembly has brought progress in the lives of the Indonesian people supported by strong political stability and security, so that the Indonesian nation has been taken into account in association the nations.

b) The entire construction of the implementation of people's sovereignty in the articles of the 1945 Constitution of the Republic of Indonesia prior to the changes rests on the formulation of Article 1 paragraph (2), i.e. sovereignty is in the hands of the people, and is carried out entirely by the People's Consultative Assembly. This provision is the embodiment of the principle of kinship in the life of the nation and state, in accordance with the mandate of the Preamble of the 1945 Constitution of the Republic of Indonesia.

c) Rearrangement of the position and authority of the MPR, including the institutional format of the DPD as a regional representation, and also the institutional format of the group delegates representing the groups. 
d) Restructuring the authority of other State Institutions, especially the Constitutional Court, which is related to the authority to conduct judicial review of the Law on the Constitution.

e) The MPR supervision function is needed for the implementation of the GBHN through the MPR trial mechanism.

f) Specifically, the MPR is authorized to:

i. Amend and enact the 1945 Constitution of the Republic of Indonesia.

ii. Set outlines rather than the direction of the state.

iii. Select and appoint the President and Vice President.

iv. Dismiss the President and/or Vice President of the 1945 Constitution of the Republic of Indonesia.

According to the theory of state administration law in Indonesia, the MPR is the only institution that has supremacy,[15] which contains two principles:

1) As a sovereign body that holds power under the law to determine everything that has been affirmed by the 1945 Constitution, it is called "legal power".

2) No rival authority, meaning that there is no rival authority both individuals and bodies that have the power to violate or override what has been decided by the MPR.

There are three reasons why adjustment is needed namely composition, position and power of the MPR to become a bicameral representative body of the people. One of them is the need for Indonesia today to start implementing a system of checks and balances in order to improve the life of the state and encourage democratization. With the existence of a representative body with two chambers, it is hoped that this institution will be able to perform its legislative and control functions better

\section{Conclusion}

The current number of job seekers (prospective workers) in Indonesia is not comparable with the number of companies seeking for employees. A lot of fresh graduates who explore the world of work and look for a job finally find a job which does not match their educational background. Thus, they have to accept the job with work experience from the very bottom level. On the other hand, a lot of companies make strict requirement for the position offered. It is related to the income of companies that are used to pay workers. It is considered that the government is not serious to overcome the problem of outsourcing. This leads the workers do not have legal certainty. In this case, the Government cannot implement the 3 (three) labor principles as stipulated by the ILO. Thus, when the work contract ends, it will be extended for years, even decades. It can be said that the Government does not reduce contract labor which is basically not in accordance with the 1945 Constitution. As a result, the outsourcing workers follow the "market flexibility" system meaning that they have no other choice to work in a particular company with an outsourcing system.

\section{Acknowledgments}

The author would like to thank and give an appreciate to the Head of Semarang State University for providing a facility to join International Conference in ICILS 2020.

\section{References}


[1] S. Arinanto, Hak Asasi Manusia Dalam Transisi Politik di Indonesia. Jakarta: Pusat Studi Hukum Tata Negara Fakultas Hukum Universitas Indonesia, 2018.

[2] A. Ilmar, Hukum Tata Pemerintahan. Jakarta: Prenada Media Group, 2018.

[3] B. Manan, Kedaulatan Rakyat, Hak Asasi Manusia dan Negara Hukum. Jakarta: Gaya Medika Pratama, 1996.

[4] K. Soetoprawiro, "Sistem Pemerintahan Republik Indonesia," in Interaksi Konstitusi dan Politik: Kontekstualisasi Pemikiran Sri Soemantri, Bandung: PSKN, Fakultas Hukum Universitas Padjajaran, 2016.

[5] Soekarno, Risalah Sidang Badan Penyelidikan Usaha-Usaha Persiapan Kemerdekaan Indonesia BPUPKI Panitia Persiapan Kemerdekaan Indonesia PPKI 28 Mei 1945 - 22 Agustus 1945. Jakarta: Sekretariat Negara RI, 1995.

[6] D. Thaib, Ketatanegaraan Indonesia: Perspektif Konstitusional. Yogyakarta: Total Media, 2009.

[7] S. Soekanto and S. Mamudji, Penelitian Hukum Normatif, Suatu Tinjauan Singkat. Jakarta: Raja Grafindo Persada, 2011.

[8] M. Mahfud, Konstitusi dan Hukum dalam Kontroversi Isu. Jakarta: Raja Grafindo Persada, 2012.

[9] K. Magnar, “Alat Perlengkapan Macam Apa MPR?," in Interaksi Konstitusi dan Politik: Kontekstualisasi Pemikiran Sri Soemantri, Bandung: PSKN, Fakultas Hukum Universitas Padjajaran, 2016.

[10] W. H. Notonagoro, Reformasi gagal selamatkan NKRI : menggugat Undang-Undang Dasar 2002 hasil amandemen, kembali ke Pancasila \& UUD '45 asli. Jakarta: Indonesia Press, 2012.

[11] A. W. Yusuf, "Membangun Sistem Demokrasi Permusyawaratan Perwakilan," in Interaksi Konstitusi dan Politik: Kontekstualisasi Pemikiran Sri Soemantri, Bandung: PSKN, Fakultas Hukum Universitas Padjajaran, 2016.

[12] T. Syahuri, Hukum konstitusi : proses dan prosedur perubahan UUD di Indonesia 1945-2002 serta perbandingannya dengan konstitusi negara laian di dunia. Bogor: Ghalia Indonesia, 2004.

[13] P. Mangunsong, Konvensi Ketatanegara Sebagai Salah Satu Sarana Perubahan Undang-Undang Dasar. Bandung: Alumni, 1992.

[14] L. P. M. P. R. Indonesia, Rekomendasi Lembaga Pengkajian MPR RI tentang Kedudukan dan Kewenangan Majelis Permusyawaratan Rakyat. Jakarta: MPR RI, 2016.

[15] J. Asshiddiqie, Pengantar Ilmu Hukum Tata Negara. Jakarta: Rajawali Pers, 2019. 